ISSN:1308-8173

Gelis Tarihi: 26.11 .2020
E-ISSN: 1308-8505

Kabul Tarihi: 20.10.2021
YIL: 2021

Online Yayın: 11.11.2021

ÖZGÜN ARAŞTIRMA
Cilt: 36 Sayı: 4 Sayfa: $913-928$

Doi: $10.24988 /$ ije.830503

\title{
$\mathrm{N}_{2} \mathrm{O}$ için Çevresel Kuznets Eğrisi Hipotezinin Test Edilmesi
}

\author{
Hacı Ahmet KARADAŞ ${ }^{1}$, Şerife Merve KOŞAROĞLU ${ }^{2}$ \\ Özet
}

Sera gazlarının en zararlılarından biri olan $\mathrm{N}_{2} \mathrm{O}$ çevreye büyük zararlar vermektedir. $\mathrm{CO}_{2}$ kadar dikkat çekmemesine rağmen, bu gazın emisyonunu azaltmak için uygulanacak politikalar sürdürülebilir bir çevre ve ekonomi için büyük önem taşımaktadır. Politikaların zamansız uygulanması verimsizliğe ve kıt kaynakların boșa kullanılmasına neden olabileceğinden, politikaların uygulanma zamanı dikkatlice seçilmelidir. Bu noktada, Çevresel Kuznets Eğrisi (ÇKE) politikaların zamanlamasının belirlenmesine büyük katkı sağlamaktadır. Bu çalıșmada, $\mathrm{N}_{2} \mathrm{O}$ salınımının ekonomik büyüme ile ilişsisini incelemek amacıyla, seçili 20 Avrupa ülkesi ve Türkiye'ye ait panel verileri kullanarak $\mathrm{N}_{2} \mathrm{O}$ salınımı için ÇKE ilişsisini araştırdık. Bu amaçla, 1992-2017 dönemine ait panel veri setine panel ARDL testi uyguladık. Panel ARDL sonuçlarına göre, $\mathrm{N}_{2} \mathrm{O}$ salınımı ile ekonomik büyüme arasında istatistiksel olarak anlamlı uzun vadeli bir iliş̧i bulunmaktadır. Bu iliş̧ki "N" șeklinde bir eğri olușturmaktadır.

Anahtar kelimeler: Çevresel Kuznets Eğrisi, $N_{2} O$ salınımı, Ekonomik Büyüme, Panel ARDL

Jel Kodu: Q01, Q15, Q53, Q56

\section{Testing Environmental Kuznets Curve Hypothesis for $\mathrm{N}_{2} \mathrm{O}$}

\begin{abstract}
$\mathrm{N}_{2} \mathrm{O}$, one of the most harmful of greenhouse gases, causes great damage to the environment. Although it does not attract as much attention as $\mathrm{CO}_{2}$, policies to reduce the emission of this gas are of great importance for a sustainable environment and economy. As the untimely implementation of policies can lead to inefficiency and waste of scarce resources, their timings should be considered carefully. At this point, the Environmental Kuznets Curve (EKC) approach makes a great contribution to the determination timings of policies. In this study, we investigated the EKC relation for $\mathrm{N}_{2} \mathrm{O}$ emission using the panel data of selected 20 European countries and Turkey, to examine the relationship between $\mathrm{N}_{2} \mathrm{O}$ emissions and economic growth. For this purpose, we applied the panel ARDL test to the panel data set for the period 1992-2017. According to the panel ARDL results, there is a statistically significant long-run relationship between $\mathrm{N}_{2} \mathrm{O}$ emission and economic growth. This relationship forms an " $N$ " shaped curve.
\end{abstract}

Keywords: Environmental Kuznets Curve, $\mathrm{N}_{2} \mathrm{O}$ Emission, Economic Growth, Panel ARDL Jel Codes: Q01, Q15, Q53, Q56

\section{INTRODUCTION}

Intensive continuation of economic activities contributes to the development of the country's economies, but it also causes an increase in environmental problems. One of the most encountered and most harmful of these problems are greenhouse emissions. Depending on economic development, intensity of natural resources and energy use in production and consumption activities is shown as the main reason for the increase in greenhouse gas emissions. In recent years, environmental problems caused by greenhouse gases have become a source of concern for the future. Especially the negative effects of climate change caused by global warming and increased in the number of endangered species has been the main reasons for this concern. Countries with different development levels

ATIF ÖNERisí (APA): Karadaş, Hacl Ahmet, Koşaroğlu, Şerife Merve. (2021). $\mathrm{N}_{2} \mathrm{O}$ için Çevresel Kuznets Eğrisi Hipotezinin Test Edilmesi. İzmir Íktisat Dergisi, 36(4). 913-928. Doi: 10.24988/ije.830503

1 Dr. Öğretim Üyesi, Sivas Cumhuriyet Üniversitesi, İktisadi ve İdari Bilimler Fakültesi, İktisat Bölümü, Merkez / SíVAS, EMAIL: hkaradas@cumhuriyet.edu.tr ORCID: 0000-0002-3088-1107

2 Dr. Öğretim Üyesi, Sivas Cumhuriyet Üniversitesi, Cumhuriyet Sosyal Bilimler Meslek Yüksekokulu, Finans-Bankacılık ve Sigortacıllk Bölümü, Merkez / SIVAS, EMAIL: mkosaroglu@cumhuriyet.edu.tr ORCID: 0000-0002-2563-5753 
have made various efforts to deal global warming to prevent these problems. In this context, determining the activities that cause greenhouse gas emissions and taking policy measures to reduce them has become one of the most important goals of the countries.

It is known that the climatic effects of greenhouse gases (GHGs) last for many years. GHGs are gaseous compounds in the atmosphere that can absorb infrared radiation, retain heat in the atmosphere, are responsible for the greenhouse effect and eventually cause global warming (Sterpu et al., 2018: 1). While Non- $\mathrm{CO}_{2}$ (carbon dioxide) GHGs (NCGGs) emissions account for almost a third of all radiative forcing in the history, almost two thirds of global NCGG emissions are caused by the land / agricultural related activities. Therefore, NCGG emissions are significant for assessing net environmental effectiveness in climate change mitigation strategies. NCGG emissions associated with land-based activities emphasize the heterogeneity of sectoral and regional emissions. NCGGs include $\mathrm{N}_{2} \mathrm{O}$ (nitrogen oxide), $\mathrm{CH}_{4}$ (methane) and F-GHGs (fluorinated greenhouse gases). Like $\mathrm{CO}_{2}$, NCGGs are gases that capture heat in the atmosphere. These gases hold more heat per molecule than $\mathrm{CO}_{2}$. Land use and land-based applications constitute the important driver of NCGG emissions (Rose and Lee, 2008: 3). In addition to the fact that the use of synthetic fertilizers has improved agricultural production, technological and medical developments have contributed to steady population growth. Over time, it has been understood that these positive developments contributed to the increase in $\mathrm{N}_{2} \mathrm{O}$ emissions in the atmosphere (Skiba and Rees, 2014: 1).

$\mathrm{N}_{2} \mathrm{O}$ and $\mathrm{CO}_{2}$ are both long-lived GHGs. Even though the atmospheric life of $\mathrm{CO}_{2}$ (hundreds to thousands of years) is much greater than $\mathrm{N}_{2} \mathrm{O}$ (about 120 years), $\mathrm{N}_{2} \mathrm{O}$ is a much more powerful GHG than $\mathrm{CO}_{2}$. $\mathrm{CH}_{4}$ is a short-lived gas

\footnotetext{
1 United States Environmental Protection Agency. Understanding Global Warming Potentials. Retrieved
}

with an atmospheric life of about 12 years. Like $\mathrm{N}_{2} \mathrm{O}, \mathrm{CH}_{4}$ is also more powerful GHG per tonne than $\mathrm{CO}_{2}$ despite its short life. However, due to the long life of $\mathrm{CO}_{2}$ emissions, human activities make the biggest contribution to climate change (Hollis et al., 2016; Sterpu et al., 2018: 1).

Since $\mathrm{N}_{2} \mathrm{O}$ can absorb infrared light strongly, it has a significant impact on the earth's radiation stock. Because of that the global warming potential (GWP) of $\mathrm{N}_{2} \mathrm{O}$ is considered to be 265298 times that of $\mathrm{CO}_{2}$ of the same mass on a 100 -year period ${ }^{1}$. So, even a very small amount of $\mathrm{N}_{2} \mathrm{O}$ is sufficient for it to be an important GHG. According to current estimates, $\mathrm{N}_{2} \mathrm{O}$ contributes about seven percent of GHG emissions in terms of global warming potential, contributing slightly less than half of the $\mathrm{CH}_{4}$. As a result, $\mathrm{N}_{2} \mathrm{O}$ ranks third behind $\mathrm{CO}_{2}$ and $\mathrm{CH}_{4}$ among the harmful gases evaluated by the Kyoto Protocol. Although $\mathrm{CO}_{2}$ emission was not much in the pre-industrial period, it is known that $\mathrm{N}_{2} \mathrm{O}$ emission was present at a high rate. Even though the atmospheric concentrations of $\mathrm{N}_{2} \mathrm{O}$ have increased since pre-industrial times with its long natural history, it is the smallest of Kyoto gases with the observed increase of only 15 percent. $\mathrm{N}_{2} \mathrm{O}$ is largely a by-product of biological processes occurring in the soil over large land areas. Since it is the smallest Kyoto gas and the product of biological process, $\mathrm{N}_{2} \mathrm{O}$ emission only leads to small increases above its natural level, which is difficult to monitor with measurements. Because of the poorly understood and highly uncertain tillage processes, $\mathrm{N}_{2} \mathrm{O}$ has been identified as the gas that contributes to the overall uncertainty of the greenhouse gas inventory (Winiwarter, 2005: 14).

$\mathrm{N}_{2} \mathrm{O}$, one of the most important forms of nitrogen (N) pollution, is the third most important anthropogenic greenhouse gas and according to National Oceanic and Atmospheric Administration (NOAA) of the US, it became the

September 20, 2020 from https://www.epa.gov/ghgemissions/understandingglobal-warming-potentials 
largest ozone-depleting substance in $2009{ }^{1}$. Extreme nitrogen pollution has been identified as one of three global environmental problems that have crossed the 'global limit'. People began to alter the natural $\mathrm{N}$ cycle as they expanded their farmland, using fire as a land clearing and management tool, and growing legumes that use atmospheric $\mathrm{N}$ to grow (Davidson and Kanter, 2014: 1). The agriculture sector is an important source of global GHG emissions, which accounts for approximately $14-17 \%$ of global anthropogenic emissions. $\mathrm{N}_{2} \mathrm{O}$ emissions from synthetic fertilizers, fertilizer applications and crop residues left on farms, account for more than $40 \%$ of total agricultural emissions. Nitrogenbased fertilizers, which are among synthetic fertilizers, are the biggest contributors to global emissions as they produce $\mathrm{N}_{2} \mathrm{O}$, which has up to 298 times greater global warming potential than $\mathrm{CO}_{2}$, during nitrification and denitrification processes (Maraseni and $\mathrm{Qu}$, 2016: 1256). Microbial processes in soil and manure (nitrification and denitrification) are recognized as the main sources of $\mathrm{N}_{2} \mathrm{O}$ emissions worldwide and in Europe. These processes require partly aerobic conditions (nitrification) and partly anaerobic conditions (denitrification). For the entire process chain, these conditions, where the soil conditions, temperature, and water availability play an important role, must occur in close areas. One of the most important parameters is the presence of nitrogen in the soil, which is the only parameter considered in the International Panel on Climate Change approach (Winiwarter, 2005: 23).

The relationship between economic growth and environmental problems has been drawing attention for a long time. Reducing the effects of environmental problems on the economy and nature has taken its place on the agenda of policy makers. In this context, knowing the relationship between economic growth and the

1 National Oceanic and Atmospheric Administration. (2009, August 28). Nitrous Oxide Now Top Ozonedepleting Emission. ScienceDaily. Retrieved September 11 , 2020 level of emission of GHGs that cause the environmental problems is of significant in establishing an appropriate theoretical basis in terms of policy making. The Environmental Kuznets Curve (EKC), developed using Kuznets's (1955) approach that examines the relationship between economic growth and income distribution, has been accepted in the economic literature and become the first hypothesis to be applied for environmental issues. The increase in the human population in the world and the change in the diet increases the agricultural $\mathrm{N}_{2} \mathrm{O}$ emission by increasing the global food demand. Since the increase in $\mathrm{N}_{2} \mathrm{O}$ emissions is an important cause of environmental degradation, attention should be paid to the activities that cause it. After examining the EKC literature, we have seen that analyses are made especially considering the level of $\mathrm{CO}_{2}$ emission not $\mathrm{N}_{2} \mathrm{O}$ emission. We believe that the reason is mostly the data unavailability. We have also noticed that $\mathrm{N}_{2} \mathrm{O}$ emission, which has environmental effects as much as $\mathrm{CO}_{2}$, is started to be used in recent studies. In this regard, we examine the EKC relation between economic growth and $\mathrm{N}_{2} \mathrm{O}$ emission of selected European countries and Turkey. In this sense, this study contributes to the literature by filling the gap in this subject.

\section{ENVIRONMENTAL KUZNETS CURVE HYPOTHESIS}

Economic growth has been one of the top priorities for economists and policy makers after World War II. In the 1960s, it was observed that environmental problems such as pollution and noise increased with economic growth (Saraç and Yağlıkara 2017: 255). In the following years, the deterioration of the environmental quality worldwide and the experienced disasters increased the sensitivity of people to the environment. With growing environmental concerns, people have increased their efforts to better understand the

www.sciencedaily.com/releases/2009/08/0908271413 44.htm 
causes of environmental degradation. At this point, economists concentrated their research on the environmental effects of economic growth. As the connection of the environment with economic growth and development has been a subject of considerable debate since the 1990s, the literature on the relationship between pollution and income growth has recently increased. The common point of these studies has been the view that environmental quality worsens in the early stages of economic growth or development and improves in later stages. In other words, it has been determined that environmental degradation initially increased faster than income and slowed down after a certain income level. This systematic relationship between income and the environment has been named as the Environmental Kuznets Curve (Dinda, 2004: 432). Grossman and Krueger (1991), inspired by the model used by Simon Kuznets in his study examining the relationship between economic growth and income distribution in 1955 , concluded that there is an "inverted-U" shaped relation between economic growth and environmental factors. In studies conducted in this sense, the EKC hypothesis is investigated by referring to this inverted-U shaped curve showing the relationship between environmental degradation and income (Koilo, 2019: 4).

According to the EKC hypothesis, economic development consists of 3 stages. In the first stage, the increase in personal income has a negative impact on local environmental factors. With industrialization, intensive use of natural resources causes an increase in the emission of polluted gases. The increase in the emission of these pollutant gases puts more pressure on the environment. In the later stages of industrialization, the increase in income causes people to value the environment more. In addition, as the regulatory institutions increase their effectiveness, the level of environmental degradation begins to decrease (Dinda, 2004: 432). Therefore, this effect reverses after the income reaches a certain turning point, that is, increase in income now leads to an improvement in environmental quality. The graphical representation of the EKC hypothesis that explains the relation of income and environmental degradation is given in Figure 1 (Karadaş and Işık, 2018: 284).

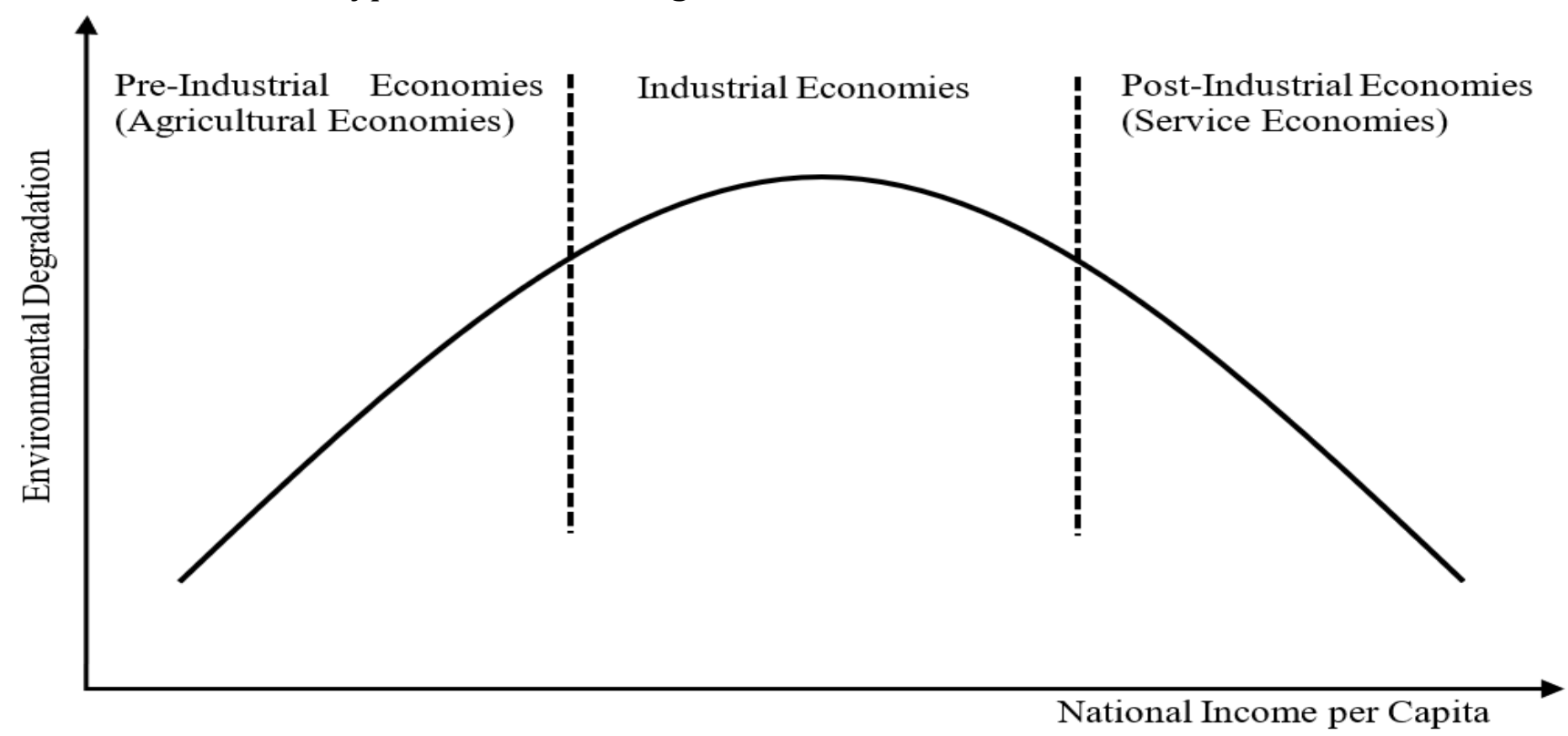

Figure 1: Stages of Industrialization

Source: (Karadaş and Işık, 2018: 284).

Pre-industrial economies, that is, agricultural economies, constitute the first stage of economic development. At this stage, most of the economic activities cause environmental 
degradation. The industrial economies are at the stage where dirty practices, such as the excessive use of natural resources because of the industrial revolution and rapid development movements in order to accelerate economic development, and increase in the release of harmful gases, etc., that reduce environmental quality. In the stage of service economies, improvements in environmental quality are observed due to shifting of dirty industries to third world countries, technological progress, innovations and decreases in general industrial production (Jošić et al. 2016: 34; Karadaş and Işılk, 2018: 284).

There are three reasons for the emergence of the EKC relation in an economy. These are:

- Environmental flexibility of income: Individuals whose living standards increase with the increase in income want to consume a better environment, a healthy life and quality products. The increase in the demand for environmental quality constitutes the main reason for the implementation of policies that will respond to this demand (Dinda, 2004: 435; Bo, 2011: 1323; Karadaş and Işık, 2018: 285).

- Technological and structural effects: While the increase in the output level in an economy increases the level of economic growth, the increase in the consumption of natural resources means environmental degradation. Continuing to increase in income causes the structure of the economy to change and create the activities that create less pollution (Dinda, 2004: 435; Bo, 2011: 1323; Koçak, 2014: 63; Karadaş and Işık, 2018: 285).

- International trade: While the environmental quality deteriorates as a result of the increase in production and therefore the use of natural resources to increase trade volume, especially exports, structural and / or technological effects arise as a result of the increase in trade, helping to improve environmental quality
(Dinda, 2004: 436; Bo, 2011: 1323; Karadaş and Işık, 2018: 285).

With the increasing interest in environmental issues, the EKC hypothesis has found its way into many studies. The data and methods used in these studies show similarities. Generally, the model given in Equation 1 is used to investigate the EKC hypothesis.

$y_{i t}=\alpha_{i}+\beta_{1} x_{i t}+\beta_{2} x_{i t}^{2}+\beta_{3} x_{i t}^{3}+\beta_{4} z_{i t}+\varepsilon_{i t}$

Where, $y$ represents the environmental indicator, $x$ represents income and $z$ represent other variables that have an impact on environmental degradation. And $i$ denotes countries, $t$ denotes time, $\alpha$ is constant, $\varepsilon$ is error term, and $\beta_{k}$ is the coefficient of the $k^{\text {th }}$ explanatory variable. According to the condition of the $\beta_{k}$ coefficients obtained from the equation, there can be 7 different types of relationships between the environment and economic growth (Karadaş and Ișık, 2018: 285286):

i. If $\beta_{1}=\beta_{2}=\beta_{3}=0$, there is no relationship between $x$ and $y$.

ii. If $\beta_{1}>0$ and $\beta_{2}=\beta_{3}=0$, there is a linear and monotonously increasing relationship between $x$ and $y$.

iii. If $\beta_{1}<0$ and $\beta_{2}=\beta_{3}=0$, there is a monotonously decreasing relationship between $x$ and $y$.

iv. If $\beta_{1}>0, \beta_{2}<0$ and $\beta_{3}=0$, there is an "inverted-U" shaped relationship between $x$ and $y$. This relationship shows the situation expressed by the EKC hypothesis.

v. If $\beta_{1}<0, \beta_{2}>0$ and $\beta_{3}=0$, there is a " $\mathrm{U}$ " shaped relationship between $x$ and $y$.

vi. If $\beta_{1}>0, \beta_{2}<0$ and $\beta_{3}>0$, there is an " $\mathrm{N}$ " shaped relationship between $x$ and $y$.

vii. If $\beta_{1}>0, \beta_{2}<0$ and $\beta_{3}<0$, there is an "inverted-N" shaped relationship between $x$ and $y$. 
Graphical representation of 6 different relationships (ii-vii) between income and environmental degradation is given in Figure 2.
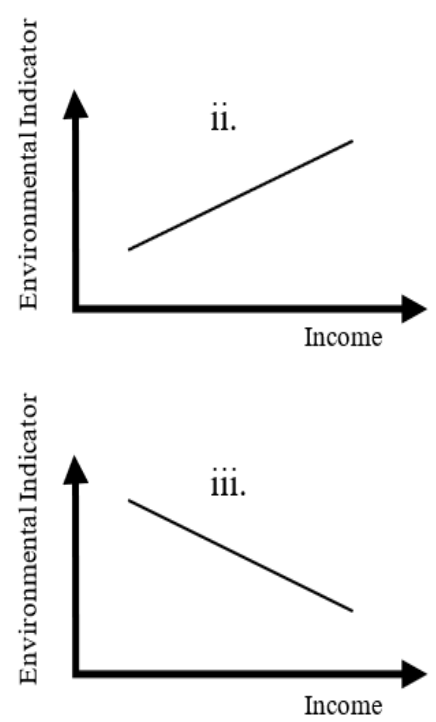
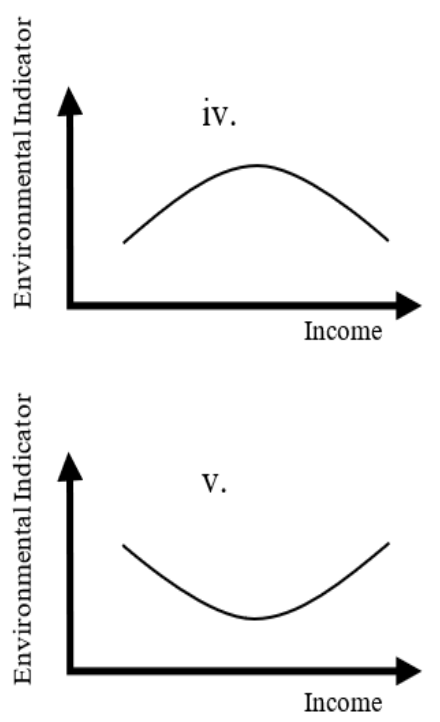
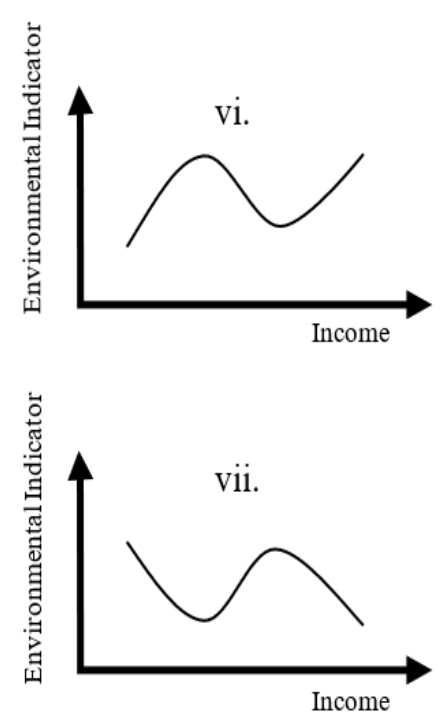

Figure 2: Possible Results of EKC in A Cubic Model Source: (Karadaş and Işık, 2018: 286)

The EKC hypothesis helps managers to decide the policies to be implemented at different development levels. For example, policies aimed at reducing greenhouse gas emissions in the first stage of EKC, that is, in an economy where income and environmental degradation increase together, will be beneficial, but ineffective in an economy where there is an inverse relationship between income and environmental degradation (Haider et al., 2020: 3).

\section{LITERATURE REVIEW}

Reviewing the literature, we have observed that there has been an increase in studies investigating the relationships between income and different environmental indicators of various countries or country groups to test the EKC hypothesis in recent years. Some of these studies are summarized in this section.

Şahinöz and Fotourehchi (2013) investigated the existence of EKC relation in 26 OECD countries in the period of 1994-2010. Results of the analysis show that there is an "N" shaped relation between per capita GDP and $\mathrm{CO}_{2}$ emission. In addition, they determined a similar relation between population density and $\mathrm{CO}_{2}$ emission

Eratas and Uysal (2014) investigated the relation between income level and pollution in BRICT countries for 1992-2010 period. The results show that there is cointegration between variables. According to the results of the analysis, there is an "N" shaped relationship between pollution and income level in BRICT countries.

Al-Mulali et al. (2016) investigated the existence of EKC relation with the panel data of selected seven region. According to results, the EKC relation is valid in Central and Eastern Europe, Western Europe, East Asia and the Pacific, South Asia, and the Americas, it is not valid in Middle East and North Africa, and SubSaharan Africa. In addition, the results show that there is a significant negative relation between renewable energy consumption and $\mathrm{CO}_{2}$ emission in the regions where the EKC relation is valid. This show that the existence of EKC relation depend on the relation between 
renewable energy consumption and $\mathrm{CO}_{2}$ emission.

Zambrano-Monserrate and Fernandez (2017) investigated the relation between $\mathrm{N}_{2} \mathrm{O}$ emission, GDP per capita, used agricultural land, and exports in Germany for 1970-2012 period. The results show that EKC hypothesis is valid in Germany for $\mathrm{N}_{2} \mathrm{O}$ emission and economic growth. In addition, while increase in the used agricultural land increases the $\mathrm{N}_{2} \mathrm{O}$ emission, increase in exports decreases the $\mathrm{N}_{2} \mathrm{O}$ emission.

Saraç and Yağlıkara (2017) investigated the existence of EKC relation in BSEC countries with panel data of 1992-2012 period. The results show that there is an inverted-U shaped relation between economic growth and $\mathrm{CO}_{2}$ emission which supports the EKC hypothesis in BSEC countries.

Yurttagüler (2017) investigated the relation between income and $\mathrm{CO}_{2}$ emission in Turkey for 1960-2011 period by Johansen cointegration test. According to results, these two variables are cointegrated. In addition, it is confirmed that there is an " $\mathrm{N}$ " shaped relationship between variables.

Cruz et al. (2018) investigated the relation between $\mathrm{CH}_{4}$ emission, economic growth, and agriculture activities in Argentina for 19702012 period by ARDL test. Results bring forward there is a dynamic relation between variables suggesting the existence of EKC in the long run. In addition, they determined that the agriculture activities decrease the $\mathrm{CH}_{4}$ emission because of the technological innovations employed in the agricultural sector in Argentina.

Sterpu et al. (2018) investigated the relation between per capita GHG emissions, gross domestic product, gross inland energy consumption, and renewable energy consumption by the panel data of $28 \mathrm{EU}$ countries for 1990-2016 period. Results of the panel cointegration test show that there is a long-run relation between these variables and the inverted U-shaped EKC hypothesis is valid for 17 of the panel countries. In addition, although the gross energy consumption increases the GHG emissions, the renewable energy consumption helps to reduce the emissions.

Sinha and Sengupta (2019) investigated the impact of renewable and fossil fuel energy consumptions on $\mathrm{N}_{2} \mathrm{O}$ emissions by the panel data of APEC countries for 1990-2015 period. The results of Westerlund and Edgerton cointegration test and Dumitrescu and Hurlin causality test show that renewable energy usage helps to reduce the $\mathrm{N}_{2} \mathrm{O}$ emission level.

Destek and Sarkodie (2019), in order to investigate the existence of EKC relation, applied causality test to the panel data economic growth, energy consumption, financial development, and ecological footprint of 11 newly industrialized countries for 19772013 period. The results show that there is an "inverted-U" shaped relation between economic growth and ecological footprint. The result of causality confirms that there is bidirectional causality relation between these two variables.

Haider et al. (2020) investigated the relation between $\mathrm{N}_{2} \mathrm{O}$ emissions, including those resulting from agriculture, economic growth, agricultural land use, and exports by the panel data of 2 country groups (the top 15 countries ranked by $\mathrm{N}_{2} \mathrm{O}$ emissions and top 18 countries ranked by share of agriculture in GDP). They create 2 separate models for $\mathrm{N}_{2} \mathrm{O}$ emissions and agricultural $\mathrm{N}_{2} \mathrm{O}$ emissions and applied Westerlund cointegration test and panel dynamic causality test. Results show that $\mathrm{N}_{2} \mathrm{O}$ emissions and economic growth are cointegrated and the EKC relation is valid for both models. In addition, it was determined that agricultural land use causes $\mathrm{N}_{2} \mathrm{O}$ emissions to increase.

Yusuf et al. (2020) investigated the relation between GHG emissions, energy consumption, and production growth by the panel data of African OPEC countries for 1970-2016 period. The 3-separate panel ARDL model is used for $\mathrm{N}_{2} \mathrm{O}, \mathrm{CO}_{2}$, and $\mathrm{CH}_{4}$ gases. The results show that 
economic growth increases both $\mathrm{CO}_{2}$ and $\mathrm{CH}_{4}$ emissions in the long-run, energy consumption increases $\mathrm{CO}_{2}, \mathrm{~N}_{2} \mathrm{O}$, and $\mathrm{CH}_{4}$ emissions in the long-run. And they confirmed that the EKC exists only in the case of $\mathrm{CH}_{4}$ emissions model.

As seen in the literature review, the studies about the EKC hypothesis are mostly concentrated on the $\mathrm{CO}_{2}$ emission. We have determined that the emission of $\mathrm{N}_{2} \mathrm{O}$, which is as important as $\mathrm{CO}_{2}$ in climate change, has not been adequately studied in the literature. Therefore, we conducted this study to fill this gap in the literature.

\section{ECONOMETRIC ANALYSIS}

In this study, in order to investigate the EKC relation for $\mathrm{N}_{2} \mathrm{O}$ emission, we conducted an econometric analysis using the panel data of selected 20 Europe countries ${ }^{1}$ (Austria, Bulgaria, Denmark, Finland, France, Germany, Greece, Hungary, Iceland, Ireland, Italy, Netherlands, Norway, Poland, Portugal, Spain, Sweden, Switzerland, United Kingdom) and Turkey for 1992-2017 period. The variables used in the analysis and their definitions are given in Table 1.

Table 1: Data tests and results

\begin{tabular}{|c|c|c|}
\hline VARIABLE & DEFINITION & SOURCE \\
\hline N2O & $\begin{array}{c}\mathrm{N}_{2} \mathrm{O} \text { emission (National total for the entire territory based on fuel sold) } \\
\text { (Tonnes) }\end{array}$ & EUROSTAT \\
\hline GDP & GDP per capita, PPP (constant 2017 international \$) & WORLDBANK \\
\hline FL & Forest land $(1000 \mathrm{ha})$ & FAOSTAT \\
\hline $\mathrm{AL}$ & Agricultural Land Use $(1000 \mathrm{ha})$ & FAOSTAT \\
\hline
\end{tabular}

In keeping with the literature, we used a cubic equation to examine the relationship between variables. The equation adapted to the variables in the study is given in Equation 2.

$L N_{i t}=\alpha_{i}+\beta_{1} L G_{i t}+\beta_{2}(L G)_{i t}^{2}+\beta_{3}(L G)_{i t}^{3}+$ $\beta_{4} L F_{i t}+\beta_{5} L A_{i t}+\varepsilon_{i t}$

$\mathrm{n}$ Equation 2, LN represents the natural logarithm of the $\mathrm{N}_{2} \mathrm{O}, \mathrm{LG}$ is the natural logarithm of the GDP, LF represents the natural logarithm of the FL and LA represents the natural logarithm of the AL. $\alpha_{i}$ is the constant, $\varepsilon_{i t}$ is the error term, and $\beta_{k}(\mathrm{k}=1,2, \cdots, 5)$ are the coefficients of the equation.

\subsection{Unit root tests}

In econometric analysis, if the variables used contain unit root (i.e., they are not stationary), there is a possibility of obtaining spurious regression in the analyzes. Therefore, before starting the analysis, it should be examined whether the variables used contain unit roots or not. In panel data analysis, there are many

\footnotetext{
${ }^{1}$ In the absence of sufficient data, econometric analysis cannot be performed. For this reason, European
}

unit root tests used in the analysis of stationarity. These tests are generally grouped as first generation and second-generation unit root tests. While the first generation unit root tests (Im-Pesaran-Shin (2003), Levin-Lin-Chu (2002), Maddala and Wu (1999) etc.) assume that there is no relationship (cross-sectional dependency) between the units forming the panel and any shock affects all units at the same rate (Mercan et al., 2015: 129), the second generation unit root tests (Fisher panel unit root test, Pesaran (2007)) panel unit root test (CIPS) etc.) assume that the units forming the panel are interconnected and not independent and that the resulting shocks affect each unit differently.

Today, it is known that economies are interconnected, and each economy has its own dynamics. For this reason, applying the firstgeneration unit root tests to a panel data set containing economic variables may result in a spurious regression problem resulting in analysis could be performed without any problems. 
biased results. To avoid this problem, first of all, it should be examined whether there is a crosssectional dependency. There are several crosssectional dependency tests such as BreuschPagan LM, Pesaran scaled LM and Pesaran CD tests. These tests can give significant or spurious results according to the cross-section (N) and time dimension (T) size of the panel data set. Breusch-Pagan LM test gives significant results when $\mathrm{N}$ is constant and $\mathrm{T} \rightarrow \infty$ (i.e., $\mathrm{T}>\mathrm{N}$ ), the Pesaran scaled LM test gives significant results when $\mathrm{T} \rightarrow \infty$ and $\mathrm{N} \rightarrow \infty$, the Bias-corrected scaled LM test gives significant results when $\mathrm{N} \rightarrow \infty$ and $\mathrm{T} \rightarrow \infty$ and Pesaran $\mathrm{CD}$ test gives significant results when $\mathrm{N}>\mathrm{T}$. The null hypothesis of these four tests is the same and is " $\mathrm{H}_{0}$ : there is no cross-section dependence between the units" (De Hoyos and Sarafidis, 2006; Karadaș, 2020a; Karadaş, 2020b; Koçbulut and Barış, 2016; Şengönül vd., 2018). Results of these tests are given in Table 2.

Table 2: Data tests and results

\begin{tabular}{|c|c|c|c|c|}
\hline \multicolumn{5}{|c|}{ Null hypothesis: No cross-section dependence (correlation) } \\
\hline & Test & Statistic & d. f. & Probability \\
\hline \multirow{4}{*}{$\mathrm{LN}$} & Breusch-Pagan LM & $3580.050 *$ & \multirow{4}{*}{190} & 0.0000 \\
\hline & Pesaran scaled LM & 173.9059* & & 0.0000 \\
\hline & Bias-corrected scaled LM & 173.5059* & & 0.0000 \\
\hline & Pesaran CD & 48.51423* & & 0.0000 \\
\hline \multirow{4}{*}{$\mathrm{LG}$} & Breusch-Pagan LM & $3872.047 *$ & \multirow{4}{*}{190} & 0.0000 \\
\hline & Pesaran scaled LM & 188.8850* & & 0.0000 \\
\hline & Bias-corrected scaled LM & 188.4850* & & 0.0000 \\
\hline & Pesaran CD & 61.33568* & & 0.0000 \\
\hline \multirow{4}{*}{ LG2 } & Breusch-Pagan LM & 3861.829* & \multirow{4}{*}{190} & 0.0000 \\
\hline & Pesaran scaled LM & 188.3609* & & 0.0000 \\
\hline & Bias-corrected scaled LM & 187.9609* & & 0.0000 \\
\hline & Pesaran CD & $61.23115^{*}$ & & 0.0000 \\
\hline \multirow{4}{*}{ LG3 } & Breusch-Pagan LM & $3851.356^{*}$ & \multirow{4}{*}{190} & 0.0000 \\
\hline & Pesaran scaled LM & 187.8236* & & 0.0000 \\
\hline & Bias-corrected scaled LM & 187.4236* & & 0.0000 \\
\hline & Pesaran CD & 61.12388* & & 0.0000 \\
\hline \multirow{4}{*}{ LA } & Breusch-Pagan LM & 1956.181* & \multirow{4}{*}{190} & 0.0000 \\
\hline & Pesaran scaled LM & $90.60317^{*}$ & & 0.0000 \\
\hline & Bias-corrected scaled LM & 90.20317* & & 0.0000 \\
\hline & Pesaran CD & 29.14849* & & 0.0000 \\
\hline \multirow{4}{*}{$\mathrm{LF}$} & Breusch-Pagan LM & 3491.637* & \multirow{4}{*}{190} & 0.0000 \\
\hline & Pesaran scaled LM & $169.3704^{*}$ & & 0.0000 \\
\hline & Bias-corrected scaled LM & $168.9704^{*}$ & & 0.0000 \\
\hline & Pesaran CD & $32.54522 *$ & & 0.0000 \\
\hline
\end{tabular}

Note: * indicates the $1 \%$ level of significance.

Since the size of the cross-section $(\mathrm{N}=20)$ is smaller than the size of the time dimension $(\mathrm{T}=26)$ in our data set, we only need to check the Breusch-Pagan LM test results. As seen in Table 2, the null hypothesis of the BreuschPagan LM test, which is "there is no crosssectional dependence between series", is rejected. This means that there is cross- sectional dependency between series, as expected. Therefore, using first generation unit root tests to examine the stationarity of variables in the analysis will yield spurious regression. For this reason, we applied the CIPS panel unit root test developed by Pesaran (2007) to the series used, and the test results are given in Table 3. 
According to the CIPS panel unit root test, the variables $\ln , \lg , \lg 2, \lg 3$ and la turned out to be stationary at the first difference, while the variable LF is stationary at level.

Table 3: Cross-Sectionally Augmented Im, Pesaran And Shin (IPS) Test for Unit Roots

\begin{tabular}{|c|c|c|c|c|}
\hline & \multicolumn{2}{|c|}{ Without trend } & \multicolumn{2}{|c|}{ With trend } \\
\hline Variable & CIPS test & Probability & CIPS test & Probability \\
\hline $\mathrm{LN}$ & -1.543 & $>0.10$ & $-2.653^{* * *}$ & 0.088 \\
\hline D.LN & $-2.786^{*}$ & $<0.01$ & $-2.834^{* *}$ & 0.027 \\
\hline LG & $-2.254^{* *}$ & 0.040 & -2.474 & $>0.10$ \\
\hline D.LG & $-2.386^{* *}$ & 0.013 & $-4.438^{*}$ & $<0.01$ \\
\hline LG2 & $-2.210^{* *}$ & 0.050 & -2.440 & $>0.10$ \\
\hline D.LG2 & $-2.364^{* *}$ & 0.017 & $-5.535^{*}$ & $<0.01$ \\
\hline LG3 & $-2.185^{* * *}$ & 0.061 & -2.540 & $>0.10$ \\
\hline D.LG3 & $-2.338^{* *}$ & 0.023 & $-5.421^{*}$ & $<0.01$ \\
\hline LA & $-2.384 * *$ & 0.012 & -2.384 & $>0.10$ \\
\hline D.LA & $-2.906^{*}$ & $<0.01$ & $-3.308^{*}$ & $<0.01$ \\
\hline LF & $-2.292^{* *}$ & 0.032 & $-3.060^{*}$ & $<0.01$ \\
\hline
\end{tabular}

Note: ${ }^{*}, * *$ and ${ }^{* * * *}$ indicate significance at $1 \%, 5 \%$ and $10 \%$ levels, respectively.

In addition to the variable-based cross-section dependency, the model-based cross-section dependency should also be checked to determine the cointegration test to be used. Therefore, we checked the cross-section dependency of the model.

Table 4: Cross Section Dependency of the model

\begin{tabular}{|l|l|l|l|}
\hline \multicolumn{4}{|l|}{ Residual Cross-Section Dependence Test } \\
\hline Test & Statistic & d.f. & Prob. \\
\hline Breusch-Pagan LM & 20.42423 & 190 & 1.0000 \\
\hline Pesaran scaled LM & $-8.699053^{*}$ & & 0.0000 \\
\hline Pesaran CD & 0.267790 & & 0.7889 \\
\hline
\end{tabular}

Note: * indicates significance at $1 \%$ level.

Similar to the variable based cross-section dependency, we only need to check the results of the Breusch-Pagan LM test since $\mathrm{N}<\mathrm{T}$. According to table 4, the null hypothesis of the Breusch-Pagan LM test is not rejected. Therefore, we decide that there is no crosssection dependency in the model.

\subsection{Panel cointegration test}

As in time series analysis, there are many cointegration tests in the literature for panel data analysis. Some of these panel cointegration tests are Panel EKK, Pedroni, Kao,
Fisher, error correction based Westerlund, panel ARDL and Durbin-Hausman cointegration tests. Among these tests, DurbinHousman test should be used if there is a crosssection dependence in the model. If there is not a cross-section dependence in the model, other tests should be used. Among the other tests, the panel least squares (LS) test is used for series stationary at level, Pedroni, Kao and Fisher panel cointegration tests are used for series stationary at the first difference. Panel ARDL cointegration test, based on PMG (Pooled Mean Group) and MG (Mean Group) estimators, is used to examine the relationship between series with different degrees of integration. That is, some of the series used in the panel ARDL test can be I (0) while others are I (1).

Since there is no cross-section dependency in the model and the series are stationary at different levels (I (0) and I (1)), the Panel ARDL cointegration test should be applied to examine the relationship between the series.

The generalized Panel ARDL ( $p, q)$ model is given in Equation 3.

$y_{i t}=\sum_{j=1}^{p} \alpha_{i} y_{i, t-j}+\sum_{k=0}^{q} \beta_{i k} X_{i, t-k}+\delta_{i}+\varepsilon_{i t}$ 
In Equation3, $y_{i t}$ denotes dependent variable, $X_{i t}$ denotes the $(k x 1)$ dimensional vector formed by independent variables that can be I $(0)$ or I (1), $\alpha_{i j}$ denote the coefficients of the lags of the dependent variable, $\beta_{i k}$ denote the coefficients of the $(k x 1)$ dimensional vector, $\delta_{i}$ denote unit specific fixed effects, $i=1,2, \ldots, \mathrm{N}, t=1,2, \ldots, \mathrm{T}, p$ and $q$ denote the appropriate lag numbers and $\varepsilon_{i t}$ denote the error term.

The error correction model obtained from the panel ARDL model is given in Equation 4.

$\Delta y_{i t}=\theta_{i}\left[y_{i, t-1}-\omega_{i} X_{i, t}\right]+\sum_{j=1}^{p-1} \rho_{i j} \Delta y_{i, t-j}+$

$\sum_{k=0}^{q-1} \beta_{i k} \Delta X_{i, t-k}+\delta_{i}+\varepsilon_{i t}$

In Equation $4, \theta_{i}=-\left(1-\alpha_{i}\right)$ is the group specific adjustment coefficient velocity (expected to be $\theta_{i}<0$ ), $\omega_{i}$ is the vector of longrun relations, $\rho_{i j}$ and $\beta_{i k}$ are dynamic short-run coefficients and ECT $=\left[y_{i, t-1}-\omega_{i} X_{i, t}\right]$ is the error correction term.

Pesaran and Smith (1995) and Pesaran et al. (1999) proposed two different estimators, MG and $\mathrm{PMG}$, against the heterogeneity problem encountered in dynamic panels.

The MG estimator, which has the least restrictive procedure and allows heterogeneity of all parameters without cross-country restrictions, derives the long-run parameters from ADRL models for individual countries. Although, individual regressions are estimated for each country, MG estimator has the calculation averages of country-specific coefficients that provide consistent estimates for long-run coefficients (Chu and Sek, 2014: 945). The long-run parameter for the $i^{\text {th }}$ unit in the ARDL model in Equation (3) is found as

$\gamma_{i}=\frac{\beta_{i}}{1-\alpha_{i}}$

and the MG estimator for all panel is obtained as

$\hat{\gamma}=\frac{1}{N} \sum_{i=1}^{N} \gamma_{i} \quad \hat{\delta}=\frac{1}{N} \sum_{i=1}^{N} \delta_{i}$.

In the PMG estimator, it is assumed that the long-run coefficients of the estimator are the same for each unit, but the short-run coefficients are free to vary. In this estimator, there is a constraint that the elements of the vector $\mathrm{W}$ in equation (4) are common for each unit. Therefore, in PMG estimator, all dynamics and ECM terms can vary. The PMG estimator's parameter estimates are consistent and are asymptotically normal for stationary regressors and also non-stationary regressors (Chu and Sek, 2014: 945).

In short, one of these two estimators (MG) assumes that there is no common point between the units in the panel, while the other (PMG) assumes that the long-run coefficients for the units in the panel are the same but the short-run coefficients are different. The fact that there are two different estimators with different assumptions reveals the necessity to choose the effective one among them. According to the assumptions of these two estimators, it is seen that the MG estimator is more effective if there is a homogeneous relationship between the units of the panel, and the PMG estimator is more effective if there is a heterogeneous relationship. To examine the homogeneity between panel units, the Delta tests can be used. Table 5 shows the results of delta tests applied to the model used in the study.

Table 5: Delta Tests

\begin{tabular}{|c|c|c|}
\hline \multicolumn{3}{|c|}{ Pesaran, Yamagata } \\
\hline \multirow{2}{*}{ adj. } & Delta & p-value \\
\cline { 2 - 3 } & $22.714^{*}$ & 0.000 \\
\hline \multicolumn{3}{|c|}{ Blomquist, Westerlund } \\
\hline & Delta & p-value \\
\hline \multirow{2}{*}{ adj. } & $11.120^{*}$ & 0.000 \\
\cline { 2 - 3 } & $13.008^{*}$ & 0.000 \\
\hline
\end{tabular}

Note: * indicates significance at $1 \%$ level.

The null hypothesis of both homogeneity tests used in the analysis is that the slope coefficients are homogeneous. As seen in Table 5, the null hypotheses of both delta tests are rejected, so it is understood that the slope coefficients are not homogeneous. Therefore, for the model, the PMG estimator is more efficient than the MG estimator. According to assumptions of the PMG estimator, the long-run coefficients are 
same for all countries and the short run coefficients are different for each country. Since we are interested with the long-run relation, we will only represent the long-run coefficients.

Now that the effective estimator has been determined, the long-run relation between the variables can be examined using this estimator. Panel ARDL test results based on PMG estimator are given in Table 6.
According to the ARDL test results, it is seen that the error correction term (ECM) is statistically significant, and its coefficient is $(\approx-$ 0.207). According to this result, there is a cointegration relationship between the variables used in the analysis in the long run. In case of any deviations from the long-run equilibrium, it is seen that the model will return

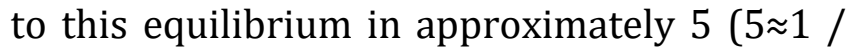
$0.207)$ periods.

Table 6: Long-Run Coefficients of ARDL Test

\begin{tabular}{|c|c|c|c|c|}
\hline Variable & Coefficient & Standard Error & t-statistic & Probability \\
\hline ECM & $-0.2077^{* * *}$ & 0.1222 & -1.6994 & 0.0916 \\
\hline \multicolumn{5}{|c|}{ Long-run Equation } \\
\hline Variable & Coefficient & Standard Error & t-statistic & Probability \\
\hline LG & $149.2074^{*}$ & 39.7280 & 3.7557 & 0.0003 \\
\hline LG2 & $-14.4945^{*}$ & 3.8984 & -3.7181 & 0.0003 \\
\hline LG3 & $0.4693^{*}$ & 0.1275 & 3.6811 & 0.0003 \\
\hline LA & $2.3214^{*}$ & 0.2476 & 9.3770 & 0.0000 \\
\hline LF & $-0.9420^{*}$ & 0.0693 & -13.5924 & 0.0000 \\
\end{tabular}

Note: ${ }^{*}$ and ${ }^{* * *}$ indicate the significance at $1 \%$ and $10 \%$ levels, respectively.

According to the long-run equation obtained from the analysis, the long-run coefficients of all variables in the model are statistically significant. When the coefficients of variables in ARDL Long-run Equation are examined, it is seen that the EKC hypothesis ("Inverted-U" shaped curve) is not valid, but the vi. Case $\left(\beta_{1}>\right.$
$0, \beta_{2}<0$ and $\beta_{3}>0$ ) given in Figure 2 is valid, i.e., there is an "N-shaped" relationship between $\mathrm{N}_{2} \mathrm{O}$ release and economic growth.

$$
\begin{aligned}
& L N_{i t}=149.2 L G_{i t}-14.49(L G)_{i t}^{2}+ \\
& 0.46(L G)_{i t}^{3}+2.32 L A_{i t}-0.94 L F_{i t}+\varepsilon_{i t}
\end{aligned}
$$

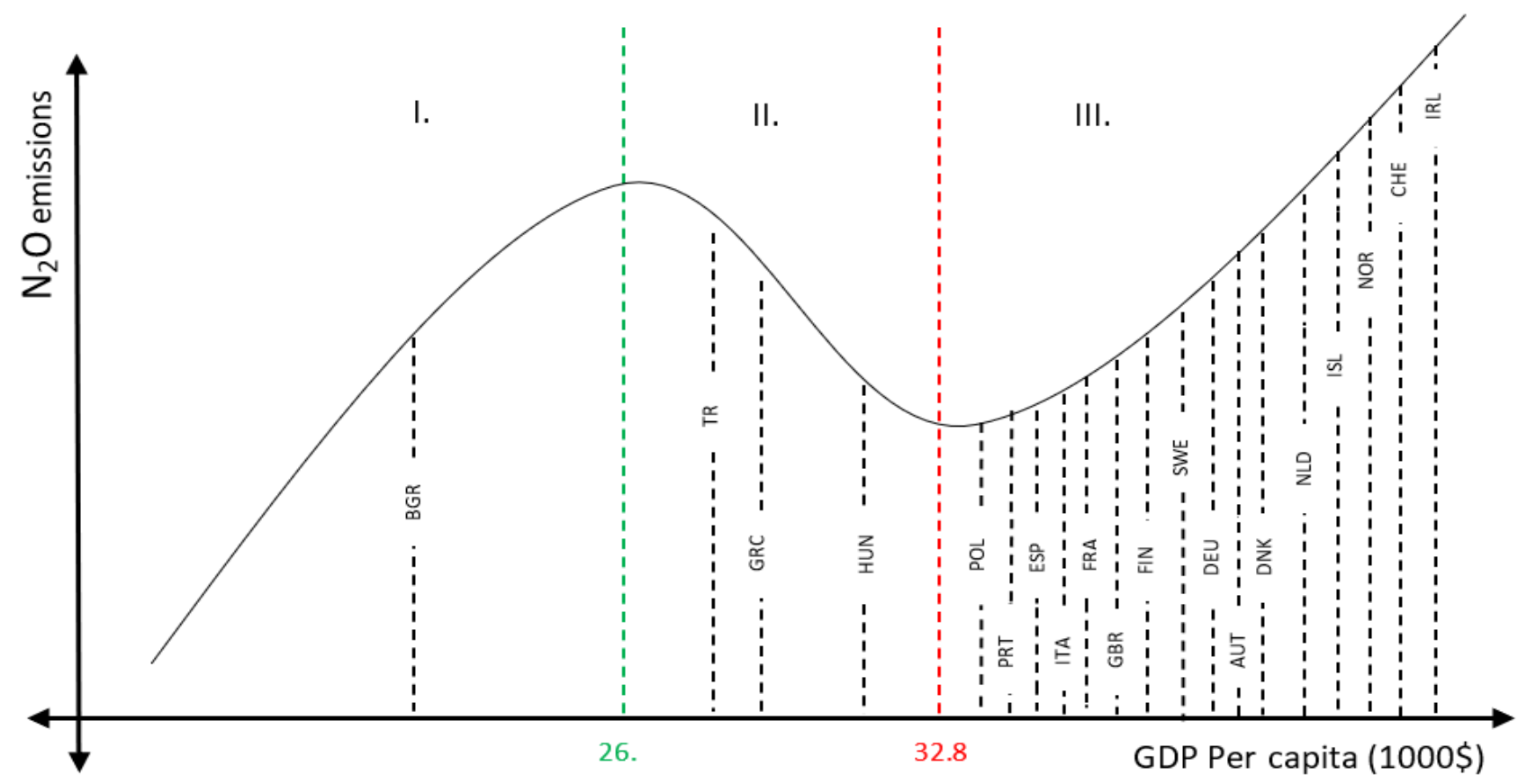

Figure 3: Graph of the Relationship Between N20 Emissions and Per Capita Income 
According to Equation 7, the increase in economic growth in the countries of the panel will cause $\mathrm{N}_{2} \mathrm{O}$ emissions to increase up to the first turning point (26664.8), then it will start to decrease until the second turning point (32830.1). If the second turning point is exceeded, the increase in economic growth will start to cause an increase in $\mathrm{N}_{2} \mathrm{O}$ emission again. This relation between $\mathrm{N}_{2} \mathrm{O}$ emission and economic growth is given in Figure 3.

As seen in Figure 3, the curve showing the relationship between $\mathrm{N}_{2} \mathrm{O}$, and growth is divided into 3 stages. In the first and third stages, economic factors will cause an increase in $\mathrm{N}_{2} \mathrm{O}$ emission as the income increases. On the contrary, economic factors will cause $\mathrm{N}_{2} \mathrm{O}$ emission to decrease automatically, in the second stage. When countries are placed into the curve according to their GDP per capita values of 2017, it is seen that Bulgaria is the only country in the first stage with a GDP value of 21.3 thousand dollars. Hence, $\mathrm{N}_{2} \mathrm{O}$ emissions in the country will increase with economic growth until the GDP per capita reaches $\$ 26.6$ thousand. Then, as the income exceeds this value, economic factors will automatically cause the $\mathrm{N}_{2} \mathrm{O}$ emission to decrease Therefore, Bulgaria needs to invest in reducing its $\mathrm{N}_{2} \mathrm{O}$ emissions until its per capita income reaches $\$ 26.6$ thousands.

The GDP per capita values of Turkey and Greece and Hungary, located in the second stage of the curve, are 27.9, 29 and 29.5 thousand dollars, respectively. Therefore, until the income level in these countries reaches the level of 32.8 thousand dollars, $\mathrm{N}_{2} \mathrm{O}$ emission will be automatically reduced by economic factors as income increases. In other words, investments to reduce $\mathrm{N}_{2} \mathrm{O}$ emissions will be unnecessary until the second turning point is reached and will not affect the reduction of emissions.

Rest of the countries of the panel are located in the third stage of the curve. It is clear that economic factors will cause an increase in $\mathrm{N}_{2} \mathrm{O}$ emissions with the increase in income in these countries. Therefore, additional investments and sanctions are required in these countries to reduce $\mathrm{N}_{2} \mathrm{O}$ emissions.

Also, according to ARDL results, the coefficients of the explanatory variables (LA and LF) were found to be statistically significant. Among the variables, the coefficient of the agricultural land is positive and (2.32), while the coefficient of the forest land variable is negative and $(-0.94)$. Accordingly, the increase in the agricultural area in the countries used in the analysis causes an increase in $\mathrm{N}_{2} \mathrm{O}$ emission, on the contrary, the increase in forest assets causes a decrease in $\mathrm{N}_{2} \mathrm{O}$ emission. If the values of the coefficients are examined, it is seen that the coefficient of the agricultural land is higher in absolute terms. This means that a $1 \%$ reduction in agricultural land will influence $\mathrm{N}_{2} \mathrm{O}$ emission approximately 2.5 times more than the increase in forest lands. For this reason, it will be beneficial to implement policies that prioritize reducing agricultural land while increasing forest land to prevent $\mathrm{N}_{2} \mathrm{O}$ emissions from causing major problems in the future.

\section{CONCLUSION}

According to the findings obtained in the study that we conducted to investigate the relationship between $\mathrm{N}_{2} \mathrm{O}$ emission and economic growth on the basis of EKC hypothesis using the panel data set, there is a long-run relationship between $\mathrm{N}_{2} \mathrm{O}$ emission and income. This relationship does not form an "inverted-U" shaped curve, that is, the EKC hypothesis, but forms an "N" shaped curve. The first and second turning points of this $\mathrm{N}$-shaped curve are $\$ 26.6$ and $\$ 32.8$ thousand, respectively. While Bulgaria is the only country located in the first stage of this curve, Turkey, Greece, and the Netherlands are located in the second stage. Rest of the countries of the panel are located in the third stage of the curve, where economic growth increases $\mathrm{N}_{2} \mathrm{O}$ emissions. These results show that the additional investments to reduce $\mathrm{N}_{2} \mathrm{O}$ emissions in Turkey, Greece, and the Netherlands would be unnecessary, however, the $\mathrm{N}_{2} \mathrm{O}$ emissions in the rest of the panel countries would increase unless they 


\section{H.A.KARADAŞ- Ș.M.KOŞAROĞLU}

implement additional investments and sanctions in this regard.

It was also determined that the agricultural and forest lands used as explanatory variables have a statistically significant relationship with the $\mathrm{N}_{2} \mathrm{O}$ emissions in the long run. While increase of the agricultural lands increase $\mathrm{N}_{2} \mathrm{O}$ emissions, increase in the forest lands lead to reduce. In this regard, policies that give importance to productivity rather than size in agricultural lands and that take environmental dimensions into account should be preferred. In this way, while high yields will be obtained from the existing agricultural lands, the reduction of forest lands will be prevented. Moreover, agricultural lands remaining idle as a result of increased yields might be converted to forest land to help to further reduce $\mathrm{N}_{2} \mathrm{O}$ emissions. In addition, when the coefficients of these two variables are examined in absolute terms, it is seen that the coefficient of agricultural lands is approximately 2.5 times of the coefficient of forest lands. This shows that a 1\% reduction of agricultural areas will correspond to an increase of $2.5 \%$ of forest areas. It is clear that the use of new and environmentally friendly technologies that will increase productivity per unit land in agricultural activities will make a great contribution to the reduction of $\mathrm{N}_{2} \mathrm{O}$ emissions. Including the agricultural areas, which will not be used as a result of increased productivity and fall into idle position, in the forest lands will contribute to the reduction of $\mathrm{N}_{2} \mathrm{O}$ emissions.

In line with the results of this study, when the countries, especially that are in the third stage of the curve, determining the policies to reduce $\mathrm{N}_{2} \mathrm{O}$ emissions, should first of all give importance to reduce the agricultural lands and transforming the idle areas into forest land. In this way, they will be able to reduce $\mathrm{N}_{2} \mathrm{O}$ emissions both quickly and effectively.

\section{REFERENCES}

Al-Mulali, U., Ozturk, I., \& Solarin, S. A. (2016). Investigating the environmental Kuznets curve hypothesis in seven regions: The role of renewable energy. Ecological indicators, 67, 267-282.

Bo, S. (2011). A literature survey on environmental Kuznets curve. Energy Procedia, 5, 1322-1325

Chu, J. F., \& Sek, S. K. (2014, July). Investigating the relationship between inflation and growth: Evidence from panel ARDL models. In AIP Conference Proceedings (Vol. 1605, No. 1, pp. 943-948). American Institute of Physics.

Cruz, J. L. S., Granda, L. E. S., \& Viteri, M. L. P. (2018). Methane emissions, economic growth and agriculture: evidence of environmental kuznets curve for Argentina. INNOVA Research Journal, 3(9), 157-171.

Davidson, E. A., \& Kanter, D. (2014). Inventories and scenarios of nitrous oxide emissions. Environmental Research Letters, 9(10), 105012.
De Hoyos, R. E., and Sarafidis, V. (2006). Testing for cross-sectional dependence in panel-data models. The stata journal, 6(4), 482-496.

Destek, M. A., \& Sarkodie, S. A. (2019). Investigation of environmental Kuznets curve for ecological footprint: the role of energy and financial development. Science of the Total Environment, 650, 2483-2489.

Dinda, S. (2004). Environmental Kuznets curve hypothesis: a survey. Ecological economics, 49(4), 431-455.

Eratas, F., \& Uysal, D. (2014). Çevresel Kuznets Eğrisi Yaklaşımının "BRICT" Ülkeleri Kapsamında Değerlendirilmesi / Environmental Kuznets Curve: An Application On " BRICT " Countries. Istanbul Üniversitesi Iktisat Fakültesi Mecmuasi, 64(1), 1 -25.

Grossman, G. M., \& Krueger, A. B. (1991). Environmental impacts of a North American free trade agreement (No. w3914). National Bureau of economic research. 
Haider, A., Bashir, A., \& ul Husnain, M. I. (2020). Impact of agricultural land use and economic growth on nitrous oxide emissions: Evidence from developed and developing countries. Science of The Total Environment, 741, 140421.

Hollis, M., de Klein, C., Frame, D., Harvey, M., Manning, M., Reisinger, A., Kerr, S. \& Robinson, A. (2016). Cows, sheep and science: A scientific perspective on biological emissions from agriculture (No. 1124-2019-2408).

Im, K. S., Pesaran, M. H., \& Shin, Y. (2003). Testing for unit roots in heterogeneous panels. Journal of econometrics, 115(1), 53-74.

Jošić, H., Jošić, M., \& Janečić, M. (2016). Testing the environmental Kuznets curve in the case of Croatia. Notitia-časopis za održivi razvoj, 2(1), 35-51.

Karadaş, H. A., \& Işık, H. B. (2018). Environmental Kuznets Curve (EKC): Is It Valid For Turkey?. Economic and Management Issues in Retrospect and Prospect, IJOPEC Publication Limited, UK, No: 2018/37: 283- 295. ISBN: 978-1-912503-58-2.

Karadaș, H. A. (2020a). Effect of Labor Force Education Level on Growth: An Analysis on Fragile Five Countries. A. Umut (Ed.), Contemporary Approaches in The Field of Economy, Finance and Management (s.43-58). Nobel Bilimsel Eserler.

Karadaş, H. A. (2020b). Seçili N-11 Ülkelerinde İşgücü Eğitim Seviyesinin Ekonomiye Etkisi. N. Balıkçıŏlu (Ed.), Makroekonomik Göstergeler Cerçevesinde N -11 Ülkeleri (s.107-138). Orion Kitabevi.

Koçak, E. (2014). Türkiye'de Çevresel Kuznets Eğrisi Hipotezinin Geçerliliği: ARDL Sınır Testi Yaklaşımı. İşletme ve İktisat Çalış̧maları Dergisi, 2(3), 62-73.

Koçbulut, Ö., and Barış, S. (2016). Avrupa Birliği Ülkelerinde İhracat ve Doğrudan Yabancı Yatırımların Kadın İstihdamı Üzerindeki Etkisi: Panel Veri Analizi. Aydın İktisat Fakültesi Dergisi, 1(2), 22-39.
Koilo, V. (2019). Evidence of the Environmental Kuznets Curve: Unleashing the Opportunity of Industry 4.0 in Emerging Economies. Journal of Risk and Financial Management, 12(3), 122.

Kuznets, S. (1955). Economic growth and income inequality. The American economic review, 45(1), 1-28.

Levin, A., Lin, C. F., \& Chu, C. S. J. (2002). Unit root tests in panel data: asymptotic and finitesample properties. Journal of econometrics, 108(1), 1-24.

Maddala, G. S., \& Wu, S. (1999). A comparative study of unit root tests with panel data and a new simple test. Oxford Bulletin of Economics and statistics, 61(S1), 631-652.

Maraseni, T. N., \& Qu, J. (2016). An international comparison of agricultural nitrous oxide emissions. Journal of Cleaner Production, 135, 1256-1266.

Mercan, M., Peker, O., \& Göçer, İ. (2015). Ham Petrol Fiyat Artışlarının Enflasyonist Etkisi: Seçilmiş OECD Ülkeleri İçin Yapısal Kırılmalı Dinamik Panel Veri Analizi. Doğuş Üniversitesi Dergisi, 16(2), 123-137.

NOAA (National Oceanic and Atmospheric Administration). (2009, August 28). Nitrous Oxide Now Top Ozone-depleting Emission. ScienceDaily. Retrieved September 11, 2020 from

www.sciencedaily.com/releases/2009/08/09 0827141344.htm

Pesaran, M. H., \& Smith, R. (1995). Estimating long-run relationships from dynamic heterogeneous panels. Journal of econometrics, 68(1), 79-113.

Pesaran, M. H., Shin, Y., \& Smith, R. P. (1999). Pooled mean group estimation of dynamic heterogeneous panels. Journal of the American statistical Association, 94(446), 621-634.

Pesaran, M. H. (2007). A simple panel unit root test in the presence of cross-section dependence. Journal of applied econometrics, 22(2), 265-312. 
Rose, S., \& Lee, H. L. (2008). Non-CO2 greenhouse gas emissions data for climate change economic analysis, GTAP Working Paper, N.43.

Şahinöz, A., \& Fotourehchi, Z. (2013). Çevresel Kuznets Eğrisi: İndirgenmiş ve Ayrıștırılmış Modellerle Ampirik Bir Analiz. Hacettepe Üniversitesi Íktisadi ve İdari Bilimler Fakültesi Dergisi, 31(1), 199-224.

Saraç, Ş., \& Yağlıkara, A. (2017). Environmental Kuznets Curve: The Evidence from BSEC Countries. Ege Academic Review, 17(2), 255264.

Sinha, A., \& Sengupta, T. (2019). Impact of energy mix on nitrous oxide emissions: an environmental Kuznets curve approach for APEC countries. Environmental Science and Pollution Research, 26(3), 2613-2622.

Skiba, U., \& Rees, B. (2014). Nitrous oxide, climate change and agriculture. CAB Rev, 9(010), 1-7.

Sterpu, M., Soava, G., \& Mehedintu, A. (2018). Impact of Economic Growth and Energy Consumption on Greenhouse Gas Emissions: Testing Environmental Curves Hypotheses on EU Countries. Sustainability, 10(9), 3327.

Şengönül, A., Karadaş, H. A., and Koşaroğlu, Ş. M. (2018). Turizme Dayalı Büyüme
Hipotezinin OECD Üyesi Olan Akdeniz Ülkeleri için Analizi. Journal of International Social Research, 11(60).

United States Environmental Protection Agency. Understanding Global Warming Potentials. Retrieved September 20, 2020 from https://www.epa.gov/ghgemissions/underst anding-global-warming-potentials

Winiwarter, W. (2005). The GAINS model for greenhouse gases-version 1.0: nitrous oxide (N20). IIASA Interim Report. IIASA, Laxenburg, Austria: IR-05-055.

Yurttagüler, İ., \& Kutlu, S. (2017). An econometric analysis of the environmental Kuznets curve: the case of Turkey. Alphanumeric Journal, 5(1), 115-126.

Yusuf, A. M., Abubakar, A. B., \& Mamman, S. 0. (2020). Relationship between greenhouse gas emission, energy consumption, and economic growth: evidence from some selected oilproducing African countries. Environmental Science and Pollution Research, 1-9.

Zambrano-Monserrate, M. A., \& Fernandez, M. A. (2017, May). An environmental Kuznets curve for N2O emissions in Germany: an ARDL approach. In Natural Resources Forum (Vol. 41, No. 2, pp. 119-127). Oxford, UK: Blackwell Publishing Ltd. 